\title{
Bioprospecting of polyhydroxyalkanoates-producing bacteria from Indonesian marine environment
}

\author{
WATUMESA A. TAN", IRA WIJAYA, TRESNAWATI PURWADARIA \\ Faculty of Biotechnology, Universitas Katolik Indonesia Atma Jaya. Kampus BSD, Jl. Raya Cisauk-Lapan No. 10, BSD City, Tangerang 15345, Banten, \\ Indonesia. Tel.: +62-21-80827200 (ext 1039); `email: tan.watumesa@atmajaya.ac.id
}

Manuscript received: 11 April 2019. Revision accepted: 23 April 2019.

\begin{abstract}
Tan WA, Wijaya I, Purwadaria T. 2019. Bioprospecting of polyhydroxyalkanoates-producing bacteria from Indonesian marine environment. Biodiversitas 20: 1309-1315. Polyhydroxyalkanoates (PHA) are potential alternates to conventional synthetic plastics. PHA production in bacteria involves PHA synthase gene encoded by phaC. In this study, we isolated PHA-producing bacteria from the coastline and 1 mile from the coastline of three beaches in Indonesia. Further phaC detection and characterization of PHA production were conducted. The isolates were subjected to phylogenetic analysis based on 16S rDNA. Red Nile staining on minimal agar revealed that twenty-three isolates showed orange fluorescent, which indicated that they accumulated PHA in their cells. PCR detection showed the presence of PHA synthase class I-encoding gene $p h a C$ in twelve isolates. One representative amplicon was sequenced to verify its identity, in which it shared $86 \%$ similarity with the PHA synthase class I-encoding gene from an uncultured bacterium. Interestingly, the production of PHA in isolate ST.PA.75, which was closely related to Vibrio sp., was 2.1-fold higher than that in the Ralstonia eutropha JMP134 control. Three isolates showed similarity with bacterial genera and/or species for which PHA producing phenotypes had never been described before TP.SWC.20, which was closely related to Microbacterium arborescens, as well as TP.SWC.33 and TP.SWC.85, which were similar to Psychrobacter spp. Phylogenetic analysis showed that the PHA producing isolates were clustered into three phyla: $\gamma$-Proteobacteria, Actinomycetes, and Bacilli. A majority of the isolates $(75 \%)$ were related to $\gamma$ Proteobacteria. In this study, we uncovered diverse novel promising strains for use in the production of PHA as a more environmentallyfriendly alternative to hydrocarbon-based plastics.
\end{abstract}

Keywords: Biodegradable plastics, marine bacteria, polyhydroxyalkanoates

\section{INTRODUCTION}

Fossil hydrocarbon-based plastics, which constitute a majority of plastics used in the world, are not degradable. For more than 50 years, global production and consumption of plastics have continued to rise (Geyer et al. 2017). Despite recycling efforts, such extensive use lead to plastic accumulation in landfills and natural environment (Al-Salem et al. 2009). Some of the plastic wastes also made their way to the ocean, and it was estimated that the amount will rise from approximately 9 million metric tons in 2015 to 16 million in 2015 (Dauvergne 2018). This poses various ecological impact on organisms living within the marine environment (Browne et al. 2015; Wilcox et al. 2016; Victor 2018). Furthermore, slow deterioration of conventional plastics may also result in microplastics, which have been reported to accumulate in animals of commercial interests that are typically used for human consumption, such as fish, oysters, and clams (Cole et al. 2011; Bessa et al. 2018). Such occurrence raises some concerns on the ingestion of microplastics by human via microplastic-contaminated marine species.

One of the approaches being pursued to overcome the above issues is the search for biodegradable plastics derived from natural ingredients, also known as bioplastics. Polyhydroxyalkanoate (PHA)-based plastics derived from prokaryotic microorganisms is a promising option for this purpose. Some prokaryotes accumulate PHA granules as a response to poor nutrition and environmental stress (Obruca et al. 2018). Similar to synthetic hydrocarbonbased plastics, PHA polymers are resistant to high temperature, with a melting temperature of around $180{ }^{\circ} \mathrm{C}$ (Madison and Huisman 1999). PHAs are generally classified into two groups based on the number of carbon atoms that build up their monomeric unit, in which shortchain-length PHAs consist of 3-5 carbon atoms, while medium-chain-length PHAs consist of 6-14 carbon atoms (Koller et al. 2017). Although its high production cost currently hinders the mass application of PHA, the global PHA market is expected to reach US\$93.5 million by 2021 , particularly for biomedical, packaging and food applications (Kourmentza et al. 2017; Koller et al. 2018).

Three major pathways for bacterial PHA biosynthesis have been reported to date. Pathway I, which is the most common, was first reported in Cupriavidus necator (previously known as Wauterisia eutropha or Ralstonia eutrophus), in which the condensation of two acetyl-CoA molecules derived for sugar metabolism was used to produce short-chain-length PHA monomers (Reinecke and Steinbuchel 2009). In the second pathway, the fatty acid $\beta$ oxidation pathway generated substrates that can be polymerized into medium-chain-length PHA by Pseudomonas olevorans from various alkanes, alkenes and alkanoates (Lageveen et al. 1992). Lastly, in Pathway III the PHA monomers are generated from simple sugars such as glucose, sucrose, and fructose via the fatty acid de novo 
biosynthesis pathway, such as in $P$. putida (Huijberts et al. 1992). The production of PHA in all three pathways involves the activity of PHA synthase $(p h a C)$. There are four major groups of this enzyme: class I, III, and IV favors the synthesis of short-chain-length PHA, while class II PhaC favors the synthesis of medium-chain-length PHA (Potter and Steinbüchel 2005; Tsuge et al. 2015; Koller 2018). PHA synthase class I accounts for the majority of PHA producing bacteria isolated to date (Yang et al. 2013).

PHA-producing bacteria have been isolated from wastewater and soil since the early 90s (Shrivastav et al. 2010; Teeka et al. 2010). In recent time, more attention has been directed towards the prospect of halophilic bacteria as low-cost PHA producers (López-Cortés et al. 2008; Quillaguamán et al. 2010; Martínez-Gutiérrez et al. 2018). In this study, we screened for PHA-producing bacteria from the marine environment in Indonesia. The PHA production in each isolate was further quantified and the genetic diversity among all isolates was determined based on $16 \mathrm{~S}$ rDNA. Present work is of importance in exploring the potential diversity of bacteria that may be used for scaled-up PHA production in the future, in effort to search for a more environmentally-friendly alternative to nondegradable plastics.

\section{MATERIALS AND METHODS}

\section{Sample collection}

Seawater samples were collected from the coastline and 1 mile from the coastline of three beaches in Indonesia: Ancol Beach, Jakarta; Panjang Beach, Bengkulu; and Serang Beach, Banten. Samples were stored in sterile conical tubes at $-20^{\circ} \mathrm{C}$ prior to further analysis.

\section{Bacterial Isolation and PHA Screening}

Seawater samples were serially diluted $\left(10^{-1}-10^{-4}\right)$ using $0.85 \%$ sodium chloride and spread on Pseudomonas agar (PA; Difco) and Sea Water Complex agar (SWC; $5 \mathrm{~g}$ peptone, $1 \mathrm{~g}$ year extract, $3 \mathrm{~mL}$ glycerol, $30 \mathrm{~g}$ sodium chloride, $20 \mathrm{~g}$ bacteriological agar per liter medium), followed by incubation at $30^{\circ} \mathrm{C}$ for $24-48$ hours. Bacterial colonies with various morphological characteristics were subsequently transferred to PA and SWC several times to obtain pure colonies. The morphology of all isolates was observed under the microscope, followed by Gram staining and spore staining. The presence of PHA granules within bacterial cells were screened using Nile Red staining (Spiekermann et al. 1999). Ralstonia eutropha JMP134 (Setiadi et al. 2015) and Escherichia coli DH5 $\alpha$ were used as positive and negative controls for PHA accumulation, respectively.

\section{Detection of phaC}

All isolates were grown on Luria Broth medium (5 g yeast extract, $10 \mathrm{~g}$ peptone, $5 \mathrm{~g}$ sodium chloride per liter medium) overnight and subjected to genomic extraction using the CTAB method (Minas et al. 2011). The presence of class I phaC in all isolates was detected through PCR amplification using three specific primers: GD (5'-
GTGCCGCC (GC) (CT) (AG) (GC)ATCAACAAGT-3'), G1R (5'-GTTCCAG (AT)ACAG (GC)A (GT) (AG)TCGAA-3'), dan G2R (5'-GTAGTTCCA (GC)A (CT)CAGGTCGTT-3') (Romo et al. 2007). PCR reactions were done using the GoTaq ${ }^{\circledR}$ Green Master Mix (Promega, AS). The PCR cycles were as follow: predenaturation at $94^{\circ} \mathrm{C}$ for $10 \mathrm{~min} ; 35$ cycles of denaturation at $94^{\circ} \mathrm{C}$ for 1 min, annealing at $56^{\circ} \mathrm{C}$ for $45 \mathrm{secs}$, extension at $72^{\circ} \mathrm{C}$ for 1 min; and post-extension at $72^{\circ} \mathrm{C}$ for 5 mins. The presence of amplified bands was verified on $1 \%$ agarose gel with ethidium bromide staining. Thermo Scientific ${ }^{\mathrm{TM}}$ GeneRuler 100 bp Plus DNA Ladder has used a marker. One amplified fragment was randomly selected and sent out for sequencing, followed by confirmation by BLASTN (www.ncbi.nlm.nih.gov).

\section{PHA production}

PHA production was done using a method described by Katırcıoglu et al. (2003). All isolates were grown on MS medium containing $10 \mathrm{~g} \mathrm{l}^{-1}$ fructose at $30^{\circ} \mathrm{C}$ and $120 \mathrm{rpm}$ for 24 hours and transferred to $50 \mathrm{~mL}$ fresh MS medium (10\%) containing $40 \mathrm{~g} \mathrm{l}^{-1}$ fructose, followed by incubation at $30^{\circ} \mathrm{C}$ and $120 \mathrm{rpm}$ for 60 hours. Cells were harvested by centrifugation at $6000 \mathrm{xg}$ for 45 minutes, suspended in 5 $\mathrm{mL}$ sterile distilled water, and lysed through sonication. The cell suspension $(2 \mathrm{~mL}$ ) was mixed to equal parts of $2 \mathrm{~N}$ $\mathrm{HCl}$ and incubated on boiling water for 2 hours. The suspension was further mixed with $5 \mathrm{~mL}$ chloroform, incubated at room temperature with $150 \mathrm{rpm}$ shaking for 2 hours, and centrifuged at $6000 \mathrm{xg}$ for 20 minutes. The lower liquid phase was collected $(1 \mathrm{~mL})$ and dried at $40^{\circ} \mathrm{C}$. The resulting pellet was mixed with $5 \mathrm{~mL}$ of concentrated $\mathrm{H}_{2} \mathrm{SO}_{4}$ by vortexing and incubated at $100^{\circ} \mathrm{C}$ for 20 minutes. The mixture was let cool to room temperature and PHA content was quantified based on its absorbance at $235 \mathrm{~nm}$ (Kunioka et al. 1988). R. eutropha JMP134 (Setiadi et al. 2015 ) and $E$. coli DH5 $\alpha$ were used as positive and negative controls for PHA production, respectively.

\section{Bacterial identification and diversity analysis}

Genomic DNA was extracted using Wizard Genomic DNA Purification Kit (Promega) following the manufacturer's instruction. The identity of each isolate was determined based on $16 \mathrm{~S}$ rDNA, as amplified using the primer pair 63f (5'-CAG GCC TAA CAC ATG CAA GTC-3') and 1387r (5'-GGG CGG WGT GTA CAA GGC3') (Marchesi et al. 1998). Sequencing was carried out at Macrogen, Korea. The sequences were compared to Genbank database using BLASTN (www.ncbi.nlm.nih.gov/blast), aligned using Clustal W (Thompson et al. 1994) and subjected to phylogenetic analysis using MEGA7 (Kumar et al. 2016) based on a neighbor-joining algorithm (Saitou and Nei 1987).

\section{RESULTS AND DISCUSSION}

\section{Bacterial isolation and PHA screening}

A total of 95 pure bacterial isolates were obtained from Pseudomonas agar and SWC agar. Upon Nile Red 
screening, 23 isolates showed orange fluorescence, in which TP.SWC.2, TP.SWC.33, ST.SWC.66 and ST.SWC.85 showed the brightest fluorescence (Table 1). Twelve of these isolates were obtained from the coastline, while eleven isolates were isolated from the $1 \mathrm{~mL}$ from coastline point. Nile Red specifically stains the PHA inclusion bodies in the cytoplasm (Spiekermann et al. 1998), yet it does not attach to other inclusion bodies, such as glycogen and polyphosphate (Anderson dan Dawes 1991). Therefore, the presence of orange fluorescence in the presence of the dye indicates that these 23 isolates may accumulate PHA granules within their cells. As false negative results may be obtained due to the presence of wax esters that also lead to positive fluorescence with Nile Red (Koller and Rodríguez-Contreras 2015), further analyses were conducted to confirm PHA production in these isolates. All isolates were subjected to morphological observation and Gram staining, as presented in Table 1.

\section{Detection of phaC}

Twelve bacterial isolates showed the presence of amplified bands of 551 bp and 491 bp upon PCR detection with the nested primer pairs GD-G1R and GD-G2R, respectively (Figure 1). This indicated that these isolates carried phaC that encoded for PHA synthase class I. Further sequence analysis on one randomly selected PCR product confirmed that the band shared $85 \%$ similarity and $76 \%$ identity to phaC and PHA synthase class I of an uncultured bacterium, respectively. Other isolates that did not show any amplicon might carry other classes of phaC, or they might be PHA degraders that accumulated PHA granules as energy storage for further catabolism.

Table 1. Morphology and Nile Red screening of suspected PHA-producing bacterial isolates

\begin{tabular}{lllll}
\hline Isolate & Sample source & Cell morphology & Gram staining & Orange fluorescence* \\
\hline PP.SWC.5 & Panjang Beach, coastline & Cocci & Negative & + \\
TT.SWC.9 & Panjang Beach, 1 mile from the coastline & Cocci & Negative & + \\
TP.SWC.20 & Panjang Beach, coastline & Cocci & Negative & ++ \\
TP.SWC.21 & Panjang Beach, coastline & Cocci & Negative & +++ \\
TP.SWC.22 & Panjang Beach, coastline & Cocci & Negative & ++ \\
TP.SWC.25 & Panjang Beach, coastline & Cocci & Negative & ++ \\
TP.SWC.31 & Panjang Beach, coastline & Rods & Negative & ++ \\
TP.SWC.32 & Panjang Beach, coastline & Cocci & Positive & ++ \\
TP.SWC.33 & Panjang Beach, coastline & Rods & Negative & ++ \\
TP.SWC.36 & Panjang Beach, coastline & Coccobacilli & Positive & ++ \\
TP.SWC.39 & Panjang Beach, coastline & Cocci & Negative & ++ \\
TP.PA.45 & Panjang Beach, coastline & Coccobacilli & Positive & + \\
ST.SWC.59 & Serang Beach, 1 mile from the coastline & Cocci & Negative & + \\
ST.SWC.63 & Serang Beach, 1 mile from the coastline & Cocci & Negative & + \\
ST.SWC.65 & Serang Beach, 1 mile from the coastline & Cocci & Negative & +++ \\
ST.SWC.66 & Serang Beach, 1 mile from the coastline & Cocci & Negative & ++ \\
ST.SWC.68 & Serang Beach, 1 mile from the coastline & Coccobacilli & Negative & ++ \\
ST.SWC.69 & Serang Beach, 1 mile from the coastline & Coccobacilli & Negative & ++ \\
ST.PA.75 & Serang Beach, 1 mile from the coastline & Cocci & Negative & ++ \\
ST.PA. 77 & Serang Beach, 1 mile from the coastline & Cocci & Negative & +++ \\
ST.SWC.85 & Serang Beach, 1 mile from the coastline & Cocci & Negative & ++ \\
AT.PA.89 & Ancol Beach, 1 mile from the coastline & Cocci & Negative & ++ \\
AP.PA.92 & Ancol Beach, coastline & Cocci & + &
\end{tabular}

Note: *Orange fluorescence indicated the presence of PHA granules within the cells as qualitatively categorized to brightest (+++), medium (++) and slight (+) fluorescence.

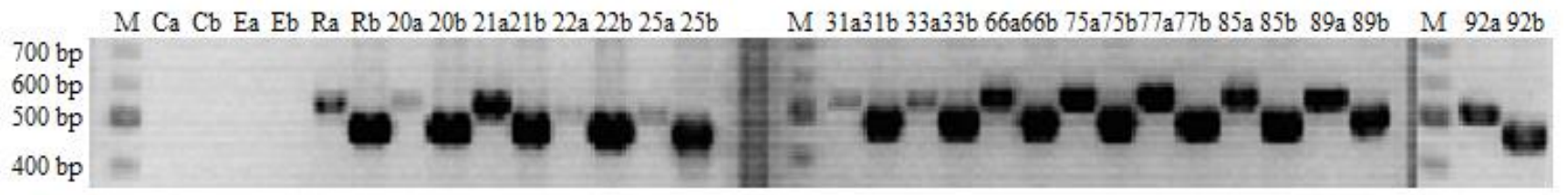

Figure 1. PCR detection of phaC using the nested primer pairs GD-G1R (a) and GD-G2R (b). C, PCR reactions in which sterile distilled water was used in place of DNA template served as contamination control; R, Ralstonia eutropha JMP134 served as positive control for phaC; E, Escherichia coli DH5 $\alpha$ served as negative control for phaC. Thermo Scientific ${ }^{\text {TM }}$ GeneRuler 100 bp Plus DNA Ladder (M) was used as a marker. 


\section{PHA production}

A majority of the isolates produced PHA in a level that is relatively similar to that in the $R$. eutropha JMP134 control (Table 2, Figure 2). An exception was demonstrated by ST.SWC.66 and ST.PA.75, which PHA production was 1.5- and 2.1-fold higher than the control, respectively (Table 2). Fructose was selected as a substrate in this experiment as this carbon source led to maximum PHA production in $R$. eutropha (Khanna dan Srivastava 2005). However, it should be noted that the isolates may have preference for other carbon sources such as glucose and sucrose. For this reason, the brightness of fluorescence following Nile Red staining might not represent PHA production level using solely one type of carbon source.

Several factors should be taken into account during PHA production. Upon the decline of growth substrate, bacteria will start producing depolymerase to hydrolyze PHA and use it as an energy source, typically by 60-62 hours post inoculation and growth on MS medium (Elbanna et al. 2004). Despite that currently known PHA producers are either obligate or facultative aerobic, PHA synthesis is promoted in oxygen- and nitrogen-limiting conditions (García-Torreiro et al. 2016; Blunt et al. 2018). In the presence of low oxygen, the NADH/NAD ratio increases and NADH concentrations inhibit citrate synthase and isocitrate dehydrogenase, leading to TCA cycle blockage. This allows for the accumulation of acetyl-CoA, therefore triggering PHA synthesis, which is then used as an alternative electron acceptor (Anderson and Dawes 1990; García-Torreiro et al. 2016). For that reason, we utilized minimal medium and slow shaking up to 60 hours for all PHA production experiments in this study.

\section{Bacterial identification and diversity analysis}

The identity of all PHA-producing isolates was revealed based on their 16S rDNA sequences (Table 2). Most isolates shared $99-100 \%$ similarities to various bacterial species recovered from the marine estuaries or other environment containing high salt concentration (Table 2). An exception was shown by isolate TP.SWC.33 and ST.SWC.66, which both showed relatively lower similarities to Psychrobacter sp. B-QPyG3 (86\%) and bacterium enrichment culture clone NAP-24 (91\%), respectively. Interestingly, despite that both ST.PA.75 and ST.PA.77 shared $100 \%$ similarity with the same reference sequence (Table 2), both isolates showed different PHA production capability (Figure 2). This indicates that PHA production may vary even up to the strain level.

All isolates were grouped into four major clusters: $\gamma$ Proteobacteria (ST.PA.75, ST.PA.77, TP.SWC.25, TP.SWC.21， TP.SWC.22， TP.SWC.33， ST.SWC.85, AP.PA.92 and AT.PA.89), Actinomycetes (TP.SWC.20), and Bacilli (ST.SWC.66 and TP.SWC.31) (Figure 3). A majority of the bacterial isolates $(75 \%)$ belong to $\gamma$ Proteobacteria. Similarly, Martínez-Gutiérrez et al. (2018) reported the abundance of $\alpha$-Proteobacteria and $\gamma$ Proteobacteria carrying PHA synthases class I-encoding genes in two hypersaline microbial mats in Mexico.

Halophiles are attractive candidates for low-cost PHA production. Of which, Halomonas spp. have been widely studied. Closely related to isolate TP.SWC.21, $H$. hydrothermalis accumulated $75.8 \%$ poly hydroxybutyrate (PHB), a type of PHA during its growth on residual glycerol as a sole carbon source (Shrivastav et al. 2010). $H$. campaniensis LS21 was able to grow in artificial seawater and mixed substrates that simulate kitchen-waste, indicating a great promise to generate PHA from low-cost substrates (Yue et al. 2014). Moreover, hypersaline conditions preferred by halophiles may inhibit the growth of non-halophiles, thus eliminating the need for substrate sterilization and therefore lowering production cost (Quillaguamán et al. 2010).

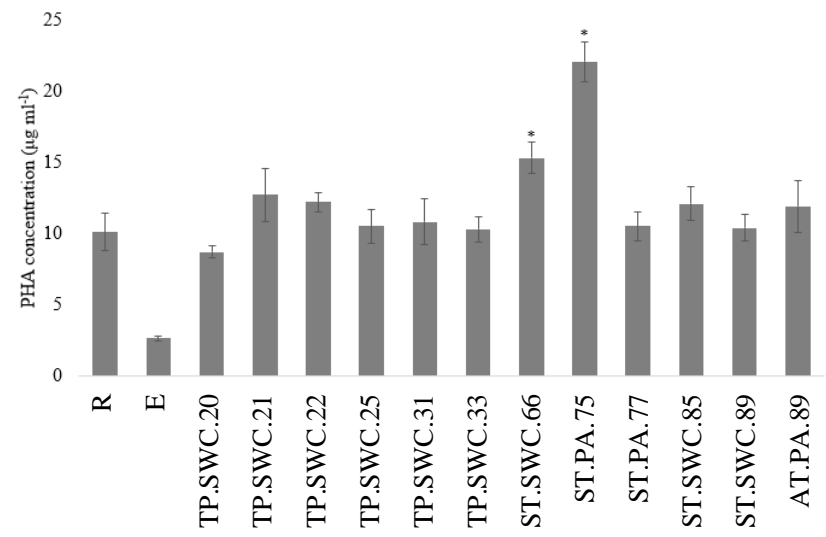

Figure 2. PHA production by marine bacterial isolates. Error bars represent standard deviation based on triplicates. Asterisks indicate significant difference at $95 \%$ degree of confidence

Table 2. Identity of PHA-producing isolates based on 16S rDNA analysis

\begin{tabular}{|c|c|c|c|c|}
\hline Isolate code & Organism & $\begin{array}{c}\text { Identity } \\
(\%)\end{array}$ & Source & Accession number \\
\hline TP.SWC.20 & Microbacterium arborescens strain 13635B & 100 & Marine sediment & EU741114.1 \\
\hline TP.SWC.21 & Halomonas hydrothermalis strain SMP3M & 100 & Rocky shores & GU938192.1 \\
\hline TP.SWC.22 & Enterobacter cloacae strain IBP-V001 & 99 & South Cina Sea & HМ021764.1 \\
\hline TP.SWC.25 & Vibrio campbellii strain $\mathrm{H} 12$ & 100 & Marine water & KY790451.1 \\
\hline TP.SWC.31 & Bacillus cereus strain 1345 & 100 & South Cina Sea & GU726854.1 \\
\hline TP.SWC.33 & Psychrobacter sp. B-QPyG3 & 86 & Marine environment & EU710703.1 \\
\hline ST.SWC.66 & Bacterium enrichment culture clone NAP-24 & 91 & Marine sediment & GU597355.1 \\
\hline ST.PA.75 & Vibrio sp. strain E466-7 & 100 & Marine sediment & MG563758.1 \\
\hline ST.PA.77 & Vibrio sp. strain E466-7 & 100 & Marine sediment & MG563758.1 \\
\hline ST.SWC.85 & Psychrobacter sp. Z19 & 100 & Seawater & HМ059659.1 \\
\hline AT.PA.89 & Aeromonas sp. BCCS 058 & 99 & Salt lake & GQ352449.1 \\
\hline
\end{tabular}




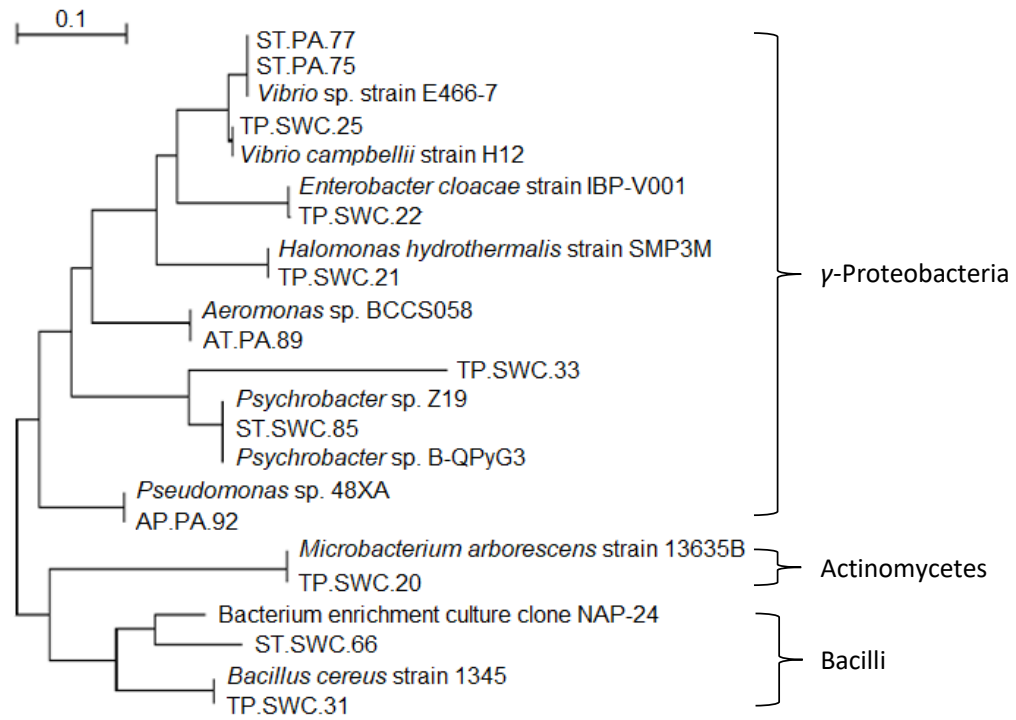

Figure 3. Diversity of PHA-producing bacterial isolates. Horizontal bar indicates genetic distance

Isolate TP.SWC.25, ST.PA.75 and ST.PA.77 were clustered with Vibrio sp. strain E466-7 and Vibrio campbellii strain H12 (Figure 3 ). V. campbellii is a marine bacterium commonly known as a pathogen in many commercially farmed marine organisms (Pande et al. 2013). As in other bioluminescent vibrios, pathogenesis is regulated by LuxR-mediated quorum sensing, which also plays a role in regulating the synthesis of PHB (Miyamoto et al. 1998; Wang et al. 2013). In a mixed microbial culture experiment, Cui et al. (2016) demonstrated the presence of Vibrio, along with Oceanicella and Piscicoccus, as PHA accumulating bacteria in glucose-enriched medium. Four Vibrio spp. strains (M11, M14, M20, and M31) closely related to $V$. natriegens were reported to synthesize PHB upon growth on diverse carbon source, including acetate, glycerol, succinate, glucose and sucrose (Chien et al. 2007).

In the presence of lactose, E. cloacae SU-1, which species was similar to TP.SWC.22, was reported to accumulate up to $94 \%$ of PHA/dry weight of the organism in lactose medium (Samrot et al. 2011). In contrast, Enterobacter cloacae sp. IBP-V001 isolated from the South China Sea was found to degrade PHA instead (Volova et al. 2011). Another species, Enterobacter aerogenes $12 \mathrm{Bi}$, was able to produce $\mathrm{PHB}$ from domestic wastewater (Ceyhan and Ozdemir 2011).

Aeromonas hydrophila 4AK4, which showed a match with isolate AT.PA.89, is a known PHA producer which whole genomic sequences have been completed (Gao et al. 2011). Such information will be useful for the improvement of PHA production in this strain via metabolic engineering approach. The crystal structure of phasin, a protein that plays a role in determining the amount of PHA accumulation and the size of PHA granules in the cells (Tian et al. 2005; Galán et al. 2011), has also been determined in this strain (Zhao et al. 2016).
Isolate TP.SWC.31 was similar to B. cereus 1345 (Table 2), and based on the primers we used for phaC detection, carried a gene that encoded for PHA synthase class I (Figure 1). This is a unique finding, as to our knowledge, all PHA-producing Bacillus spp. identified to date produce PHA synthase class IV (Tsuge et al. 2015; Kihara et al. 2017). Despite that, both classes of enzymes favor short-chain-length PHA polymerization (Potter and Steinbüchel 2005; Tsuge et al. 2015), PHA synthases belonging to Class I consist of one catalytic PhaC subunit, while those belonging to Class IV are composed of PhaC and PhaR subunits (Tsuge et al. 2015).

Three of our isolates showed similarity with bacterial genera and/or species for which PHA producing phenotypes had never been described before. Isolate TP.SWC.33 and ST.SWC.85 were closely related to Psychrobacter spp. (Table 2). Members of this genus are typically psychrophilic or psychrotolerant, halotolerant, and cohabitate in the ocean (Bowman et al. 1997). Although no specific PHA-producing Psychrobacter strain has been isolated to date, this genus was detected in abundance in an activated sludge in which PHA was accumulated (Liu et al. 2013). The ability of Psychrobacter to thrive in both warm and cold environment is a desirable characteristic for industrial purposes (Rodrigues et al. 2009). In addition, TP.SWC.20 shared 100\% similarity with Microbacterium arborescens. To date, Microbacterium barkeri DSM 20145 is the only Microbacterium sp. reported with the ability to accumulate poly (3-hydroxybutyrate) (PHB) or any other types of PHA (Shivakumar 2012). The isolate accumulated $0.6 \mathrm{gL}^{-1} \mathrm{PHB}$ under nitrogen-deficient conditions in the presence of glucose and yeast extract (Shivakumar 2012).

López-Cortés et al. (2008) compared the PHAproducing bacterial composition in polluted versus pristine environment using $16 \mathrm{~S}$ rDNA denaturing gradient gel 
electrophoresis (DGGE), and showed that the bacterial community at the polluted site was more complex and diverse than at the pristine site, which might be due to a difference in organic and inorganic nutrient availability. Compared to Panjang Beach and Serang Beach, Ancol Beach is relatively more polluted, as it is exposed to more human activities, including tourism and fisheries. However, only two PHA-producing isolates from Ancol Beach were recovered from the site (Table 1). It is possible that such environment harbors many bacteria that cannot be cultivated artificially. A metagenomic approach based on $16 \mathrm{~S}$ rDNA, such as DGGE, amplified ribosomal DNA restriction analysis, or high throughput sequencing will provide more thorough information on the bacterial community in marine environment (Tseng and Tang 2014). As the Indonesian marine estuaries harbor a diverse array of life, such information will complement our findings in effort to explore bacterial isolates that are promising for future production of PHA as a more environmentallyfriendly substitute to conventional hydrocarbon-based plastics.

\section{ACKNOWLEDGEMENTS}

This study was funded by the Faculty of Biotechnology, Atma Jaya Catholic University, Indonesia research grant.

\section{REFERENCES}

Al-Salem SM, Lettieri P, Baeyens J. 2009. Recycling and recovery routes of plastic solid waste (PSW): a review. Waste Manag 29: 2625-2643.

Anderson AJ, Dawes EA 1990. Occurrence, metabolism, metabolic role and industrial uses of bacterial polyhydroxyalkanoates. Microbiol Rev 54: 450-472.

Bessa F, Barría P, Neto JM, Frias JPGL, Otero V, Sobral P, Marques JC. 2018. Occurrence of microplastics in commercial fish from a natura estuarine environment. Mar Pollut Bull 128: 575-584. DOI: 10.1016/j.marpolbul.2018.01.044

Blunt W, Sparling R, Gapes DJ, Levin DB, Cicek N. 2018. The role of dissolved oxygen content as a modulator of microbial polyhydroxyalkanoate synthesis. World J Microbiol Biotechnology 34 (8): 106. DOI: 10.1007/s11274-018-2488-6.

Bowman J, McCamon S, Brown M, Nichols D, McMeekin TA. 1997. Diversity and association of Psychrophilic bacteria in Antarctic sea ice. Appl Environ Microbiol 63: 3068-3078.

Browne MA, Underwood AJ, Chapman MG, Williams R, Thompson RC, van Franeker JA. 2015. Linking effects of anthropogenic debris to ecological impacts. Proc Royal Soc B: Biol Sci 282 (1807): 20142929. DOI: $10.1098 / \mathrm{rspb} .2014 .2929$

Ceyhan N, Ozdemir G. 2011. Poly- $\beta$-hydroxybutyrate (PHB) production from domestic wastewater using Enterobacter aerogenes $12 \mathrm{Bi}$ strain. Af J Microbiol Res 5 (6): 690-702.

Chien CC, Chen CC, Choi MH, Kung SS, Wei YH. 2007. Production of poly- $\beta$-hydroxybutyrate (PHB) by Vibrio spp. isolated from marine environment. J Biotechnology 132 (3): 259-263. DOI: 10.1016/j.jbiotec.2007.03.002

Cole M, Lindeque P, Halsband C, Galloway TS. 2011. Microplastics as contaminants in the marine environment: A review. Mar Pollut Bull 62: 2588-2597. DOI: 10.1016/j.marpolbul.2011.09.025

Cui YW, Zhang HY, Lu PF, Peng YZ. 2016. Effects of carbon sources on the enrichment of halophilic polyhydroxyalkanoate-storing mixed microbial culture in an aerobic dynamic feeding process. Sci Rep 6: 30766. DOI: $10.1038 /$ srep30766

Dauvergne P. 2018. Why is the global governance of plastic failing the oceans? Global Environ Chang 51: 22-31. DOI: 10.1016/j.gloenvcha.2018.05.002
Elbanna K, Lutke-Eversloh T, Jendrossek D, Luftmann H, Steinbuchel A. 2004. Studies on the biodegradability of polythioester copolymers and homopolymers by polyhydroxyalkanoate (PHA)-degrading bacteria and PHA depolymerases. Arc Microbiol 182: 212-225. DOI: 10.1007/s00203-004-0715-Z

Galán B, Dinjaski N, Maestro B, De Eugenio LI, Escapa IF, Sanz JM, García JL, Prieto MA. 2011. Nucleoid-associated PhaF phasin drives intracellular location and segregation of polyhydroxyalkanoate granules in Pseudomonas putida KT2442. Mol Microbiol 79 (2): 402 418. DOI: 10.1111/j.1365-2958.2010.07450.x

Gao X, Jian J, Li WJ, Yang YC, Shen XW, Sun ZR, Wu Q, Chen GQ. 2013. Genomic study of polyhydroxyalkanoates producing Aeromonas hydrophila 4AK4. Appl Microbiol Biotechnol 97 (20): 9099-9109. DOI: 10.1007/s00253-013-5189-y

García-Torreiro M, Lu-Chau TA, Lema JM. 2016. Effect of nitrogen and/or oxygen concentration on poly (3-hydroxybutyrate) accumulation by Halomonas boliviensis. Bioproc Biosyst Eng 39 (9): 1365-1374. DOI: 10.1007/s00449-016-1612-y

Geyer R, Jambeck JR, Law KL. 2017. Production, use, and fate of all plastics ever made. Sci Advances 3 (7): e1700782. DOI: 10.1126/sciadv.1700782

Huijberts GN, Eggink G, de Waard P, Huisman GW, Witholt B. 1992. Pseudomonas putida KT2442 cultivated on glucose accumulates poly (3-hydroxy alkanoates) consisting of saturated and unsaturated monomers. Appl Environ Microbiol 58: 536-544.

Katırcıoğlu H, Aslım B, Yüksekdað ZN, Mercan N, Beyatlı Y. 2003. Production of poly- $\beta$-hydroxybutyrate (PHB) and differentiation of putative Bacillus mutant strains by SDS-PAGE of total cell protein. Af J Biotechnol 2 (6): 147-149.

Khanna S, Srivastava AK. 2005. Statistical media optimization studies for growth and PHB production by Ralstonia eutropha. Process Biochem 40: 2173-2182. DOI: 10.1016/j.procbio.2004.08.011

Kihara T, Hiroe A, Ishii-Hyakutake M, Mizuno K, Tsuge T. 2017. Bacillus cereus-type polyhydroxyalkanoate biosynthetic gene cluster contains R-specific enoyl-CoA hydratase gene. Biosci Biotechnol Biochem 81 (8): 1627-1635. DOI: 10.1080/09168451.2017.1325314

Koller M, Rodríguez-Contreras A. 2015. Techniques for tracing PHA-producing organisms and for qualitative and quantitative analysis of intra-and extracellular PHA. Eng Life Sci 15 (6): 558-581. DOI: 10.1002/elsc.201400228

Koller M, Maršálek L, de Sousa Dias MM, Braunegg G. 2017. Producing microbial polyhydroxyalkanoate (PHA) biopolyesters in a sustainable manner. New Biotechnol 25 (37): 24-38. DOI: 10.1016/j.nbt.2016.05.001

Koller M. 2018. Chemical and biochemical engineering approaches in manufacturing polyhydroxyalkanoate (PHA) biopolyesters of tailored structure with focus on the diversity of building blocks. Chem Biochem Eng Q 32 (4): 413-438. DOI: 10.15255/CABEQ.2018.1385

Koller M. 2018. Biodegradable and biocompatible polyhydroxyalkanoates (PHA): Auspicious microbial macromolecules for pharmaceutical and therapeutic applications. Molecules 23 (2): 362. DOI: 10.3390/molecules23020362

Kourmentza C, Plácido J, Venetsaneas N, Burniol-Figols A, Varrone C, Gavala HN, Reis MAM. 2017. Recent advances and challenges towards sustainable polyhydroxyalkanoate (PHA). Bioeng (Basel) 4 (2): 55. DOI: 10.3390/bioengineering4020055

Kumar S, Stecher G, Tamura K. 2016. MEGA7: Molecular evolutionary genetics analysis version 7.0 for bigger datasets. Mol Biol Evol 33 (7): 1870-1874. DOI: 10.1093/molbev/msw054

Kunioka M, Nakamura Y, Doi Y. 1988. New bacterial copolyesters produced in Alcaligenes eutrophus from organic acids. Polym Commun 29: 174-176.

Lageveen RG, Huisman GW, Preusting H, Ketelaar P, Eggink G and Witholt B. 1988. Formation of polyesters by Pseudomonas oleovorans: effect of substrates on formation and composition of poly- (R)-3-hydroxyalkanoates and poly- (R)-3-hydroxyalkenoates. Appl Environ Microbiol 54: 2924-2932.

Liu C, Wang H, Xing W, Wei L. 2013. Composition diversity and nutrition conditions for accumulation of polyhydroxyalkanoate (PHA) in a bacterial community from activated sludge. Appl Microbiol Biotechnol 97 (21): 9377-9387. DOI: 10.1007/s00253-013-5165-6

López-Cortés A, Lanz-Landázuri A, García-Maldonado JQ. 2008. Screening and isolation of PHB-producing bacteria in a polluted marine microbial mat. Microb Ecol 56: 112-120. DOI: 10.1007/s00248-007-9329-8 
Madison LL, Huisman GW. 1999. Metabolic engineering of poly (3 hydroxyalkanoates): from DNA to plastic. Microbiol Mol Biol Rev 63: 21-53.

Marchesi JR, Sato T, Weightman AJ, Martin TA, Fry JC, Hiom SJ, Wade WG. 1998. Design and evaluation of useful bacterium-specific PCR primers that amplify genes coding for bacterial 16S rRNA. Appl Environ Microbiol 64 (2): 795-799.

Martínez-Gutiérrez CA, Latisnere-Barragán H, García-Maldonado JQ, López-Cortés A. 2018. Screening of polyhydroxyalkanoate-producing bacteria and $\mathrm{PhaC}$-encoding genes in two hypersaline microbial mat from Guerrero Negro, Baja California Sur, Mexico. Peer J 6: e4780. DOI: $10.7717 /$ peerj.4780

Minas K, McEwan NR, Newbold CJ, Scott KP. 2011. Optimization of a high-throughput CTAB-based protocol for the extraction of qPCRgrade DNA from rumen fluid, plant and bacterial pure cultures. FEMS Microbiol Lett 325 (2): 162-169. DOI: 10.1111/j.1574 6968.2011.02424.x

Miyamoto CM, Sun W, Meighen EA. 1998. The LuxR regulator protein controls synthesis of polyhydroxybutyrate in Vibrio harveyi. Biochim Biophys Acta 1384: 356-364. DOI: 10.1016/S0167-4838 (98)00028-4

Obruca S, Sedlacek P, Koller M, Kucera D, Pernicova I. 2018 Involvement of polyhydroxyalkanoates in stress resistance of microbial cells: Biotechnological consequences and applications. Biotechnol Advan $36 \quad$ (3): 856-870. DOI 10.1016/j.biotechadv.2017.12.006

Pande GS, Natrah FM, Sorgeloos P, Bossier P, Defoirdt T. 2013. The Vibrio campbellii quorum sensing signals have a different impact on virulence of the bacterium towards different crustacean hosts. Vet Microbiol 167 (3-4): 540-545. DOI: 10.1016/j.vetmic.2013.08.021

Potter M, Steinbüchel A. 2005. Poly (3-hydroxybutyrate) granuleassociated proteins: impacts on poly (3-hydroxybutyrate) synthesis and degradation. Biomacromolecules 6: 552-560. DOI $10.1021 / \mathrm{bm} 049401 \mathrm{n}$

Quillaguamán J, Guzmán H, Van-Thuoc D, Hatti-Kaul R. 2010. Synthesis and production of polyhydroxyalkanoates by halophiles: Curren potential and future prospects. Appl Microbiol Biotechnol 85: 1687 1696. DOI: 10.1007/s00253-009-2397-6

Reinecke F, Steinbuchel A. 2009. Ralstonia eutropha strain H16 as a model organism for PHA metabolism and for biotechnological production of technically interesting biopolymers. J Mol Microbiol Biotechnol 16: 91-102. DOI: 10.1159/000142897

Rodrigues DF, Jesus EC, Ayala-del-Río HL, Pellizari VH, Gilichinsky D, Sepulveda-Torres L, Tiedje JM. 2009. Biogeography of two coldadapted genera: Psychrobacter and Exiguobacterium. Int Soc Microb Ecol J 3 (6): 658-665. DOI: 10.1038/ismej.2009.25

Romo DMR, Grosso MV, Solano NCM, Castaño DM. 2007. A mos effective method for selecting a broad range of short and medium chain-length polyhydroxyalkanoate producing microorganisms. Electron J Biotechnol 10: 348-357. DOI: 10.4067/S0717 34582007000300002

Saitou N, Nei M. 1987. The neighbor-joining method: a new method for reconstructing phylogenetic trees. Mol Biol Evol 4 (4): 406-425. DOI: 10.1093/oxfordjournals.molbev.a040454

Samrot AV, Avinesh RB, Sukeetha SD, Senthilkumar P. 2011 Accumulation of poly[ (R)-3-hydroxyalkanoates] in Enterobacter cloacae SU-1 during growth with two different carbon sources in batch culture. Appl Biochem Biotechnol 613 (1): 195-203. DOI: 10.1007/s12010-010-9028-7

Setiadi T, Aznury M, Trianto A, Pancoro A. 2015. Production of polyhydroxyalkanoate (PHA) by Ralstonia eutropha JMP134 with volatile fatty acids from palm oil mill effluent as precursors. Water Sci Technol 72 (11): 1889-1895. DOI: 10.2166/wst.2015.391
Shivakumar S. 2012. Accumulation of poly (3-hydroxybutyrate) by Microbacterium barkeri DSM 20145. Turk J Biol 36 (2): 225-232. DOI: $10.3906 /$ biy-1103-2

Shrivastav A, Mishra SK, Shethia B, Pancha I, Jain D, Mishra S. 2010. Isolation of promising bacterial strains from soil and marine environment for polyhydroxyalkanoates (PHAs) production utilizing Jatropha biodiesel byproduct. Int J Biol Macromol 47: 283-287. DOI: 10.1016/j.ijbiomac.2010.04.007

Spiekermann P, Rehm BHA, Kalscheuer R, Baumeister D, Steinbuchel A. 1999. A sensitive, viable-colony staining method using nile red for direct screening of bacteria that accumulate polyhydroxyalkanoic acids and other lipid storage compounds. Arc Microbiol 171: 73-80. DOI: $10.1007 / \mathrm{s} 002030050681$

Teeka J, Imai T, Cheng X, Reungsang A, Higuchi T, Yamamoto K, Sekine M. 2010. Screening of PHA-producing bacteria using biodiesel-derived waste glycerol as a sole carbon source. J Water Environ Technol 8 (4): 373-381. DOI: 10.2965/jwet.2010.373

Tian S, Lai W, Zheng Z, Wang H, Chen G. 2005. Effect of overexpression of phasin gene from Aeromonas hydrophila on biosynthesis of copolyesters of 3-hydroxybutyrate and 3hydroxyhexanoate. FEMS Microbiol Lett 244 (1): 19-25. DOI: 10.1016/j.femsle.2005.01.020

Tseng CH, Tang SL. 2014. Marine microbial metagenomics: from individual to the environment. Int J Mol Sci 15 (5): 8878-92. DOI: 10.3390/ijms 15058878

Tsuge T, Hyakutake M, Mizuno K. 2015. Class IV polyhydroxyalkanoate (PHA) synthases and PHA-producing Bacillus. Appl Microbiol Biotechnol 99 (15): 6231-6240. DOI: 10.1007/s00253-015-6777-9

Thompson JD, Higgins DG, Gibson TJ. 1994. CLUSTAL W: improving the sensitivity of progressive multiple sequence alignment through sequence weighting, position-specific gap penalties and weight matrix choice. Nucleic Acid Res 22 (22): 4673-4680. DOI: 10.1093/nar/22.22.4673

Victor D. 2018. 1,000 Pieces of plastic found inside dead whale in Indonesia. New York Times, Nov. 21, 2018. https: //www.nytimes.com/2018/11/21/world/asia/whale-plasticsindonesia.html [1 April 2019]

Volova TG, Boyandin AN, Vasil'ev AD, Karpov VA, Kozhevnikov IV, Prudnikova SV, Rudnev VP, Xuån BB, Dũng VV, Gitel'Zon II. 2011. Biodegradation of polyhydroxyalkanoates (PHAs) in the South China Sea and identification of PHA-degrading bacteria. Microbiology 80 (2): 252. DOI: 10.1134/S0026261711020184

Wang Z, Lin B, Mostaghim A, Rubin RA, Glaser ER, Mittraparp-arthorn P, Thompson JR, Vuddhakul V, Vora GJ. 2013. Vibrio campbellii hmgA-mediated pyomelanization impairs quorum sensing, virulence, and cellular fitness. Front Microbiol 4: 379. DOI: 10.3389/fmicb.2013.00379

Wilcox C, Mallos NJ, Leonard GH, Rodriguez A, Hardestya BD. 2016. Using expert elicitation to estimate the impacts of plastic pollution on marine wildlife. Mar Policy 65: 107-114. DOI: 10.1016/j.marpol.2015.10.014

Yang C, Zhang W, Liu R, Zhang C, Gong T, Li Q, Wang S, Song C. 2013. Analysis of polyhydroxyalkanoate (PHA) synthase gene and PHA-producing bacteria in activated sludge that produces PHA containing 3-hydroxydecanoate. FEMS Microbiol Lett 346 (1): 56-64. DOI: $10.1111 / 1574-6968.12201$

Yue H, Ling C, Yang T, Chen X, Chen Y, Deng H, Wu Q, Chen J, Chen G-Q. 2014. A seawater-based open and continuous process for polyhydroxyalkanoates production by recombinant Halomonas campaniensis LS21 grown in mixed substrates. Biotechnol Biofuels 7: 108. DOI: 10.1186/1754-6834-7-108

Zhao H, Wei H, Liu X, Yao Z, Xu M, Wei D, Wang J, Wang X, Chen GQ. 2016. Structural insights on PHA binding protein PhaP from Aeromonas hydrophila. Sci Rep 6: 39424. DOI: 10.1038/srep39424 